\title{
A SIMPLIFIED ASSESSMENT MODEL OF ENVIRONMENTAL GEOLOGY SUITABILITY COMBINED WITH IN-SITU INFILTRATION TEST FOR STORMWATER MANAGEMENT AND APPLICATION
}

\author{
WANG, J. J. - WANG, S.W. - WANG, X.Y. - SUN, L.* \\ The Institute of Hydrogeology and Environmental Geology \\ No. 268, Zhonghua North Road, Shijiazhuang 050061, Hebei, China \\ *Corresponding author \\ e-mail:Tairan_W@163.com \\ (Received 23 ${ }^{\text {rd }}$ Apr 2019; accepted $4^{\text {th }}$ Jul 2019)
}

\begin{abstract}
Stormwater management is the core of sponge city construction whose essence is to solve the urban water problem by means of seepage, storage, purification, utilization and drainage. From the environmental geology point of view, this paper mainly consider the geological properties of sponge capacity in the construction of sponge city. Based on a large number of in-situ water infiltration tests and boreholes, two indexes that sponge infiltration and sponge storage are put forward to study and analyze the maximum depth of rainfall infiltration and the infiltration velocity of surface soil under the original sponge geological conditions. These two indexes can directly and effectively represent and summarize the environmental geological suitability in the construction of sponge cities. Moreover, these two indexes are easy to understand, have a strong universality, and easy to promote. Finally, taking Xinxiang city in central China as an example, the environmental geological suitability of Xinxiang sponge city construction is evaluated.
\end{abstract}

Keywords: rainfall-runoff; sponge infiltration capacity; sponge storage capacity; stability evaluation

\section{Introduction}

Based on China's national conditions, China is experiencing and will continue to experience a period of rapid urbanization. Urbanization promotes the modernization of the country and the rapid development of the economy. At the same time, the immaturity of the development of urbanization also bring a series of "urban diseases" (Burns, 2012; Carter, 2007; Che, 2015), such as urban water logging, water shortage, water pollution and water ecological degradation. Due to the fact that urban water problem is very complex and still in its infancy, many standards such as construction principle, development mode and index system of sponge city have not been perfected (Wang et al., 2017; Zhang et al., 2016; Yu et al., 2015; Wu et al., 2016; Qiu, 2015; Hu et al., 2015; Hu et al., 2015a, b; Wang et al., 2015; Song et al., 2007), and are still in the process of exploration.

In the 1970s, the United States was the earliest to adopt rainwater flood detention and control measures for urban water problems. However, this measure not only failed to solve the problem of rainwater flood, but also destroyed the urban water ecological balance and polluted the urban water environment due to human engineering activities. By the early 1990s, Maryland (US EPA, 2000a) was the first to propose the concept of "Low Impact Development" (LID). The main connotation is: in the process of land development, the rainfall runoff is controlled by the site to reduce the runoff and rainwater pollution load (Benedict, 2000; US EPA, 2012b). The concept was quickly accepted and developed by Australia, New Zealand and some European countries 
(2015) by whom natural and harmonious new urban planning concepts such as "WaterSensitive Urban Planning" (Hoyer et al., 2011) and "Sustainable Drainage System" (D'Arcy et al., 2000; CIRIA, 2015) were put forward on the basis of LID. Relevant German institutions classified (Ministerium fuer Umwelt, 2001) the runoff water quality of different catchments based on different geographical factors, environmental conditions, geological conditions, etc. (Council, 2008; Dong, 2011; Wanielista, 1993), used GIS technology to plan and design the rainwater treatment plan, combined the water quality conditions and disposal purposes of each city, and decided the final disposal facility (Geiger, 2001; Gantner, 2003). North American scholars (Ji, 2014) proposed the study of rainwater micro-management based on the existing natural system, retaining important hydrological characteristics and functions, adopting the favorable conditions and constraints of rainwater management at the basin scale so as to mitigate the damage to the hydrological ecological environment and restore the regional hydroecological environment as much as possible. The "Optimal Management Practices for Rainwater" research conducted by Sweden and Denmark (Martin, 2011; Revit, 2003) combines hydrological characteristics, landscape design, environmental control, and management systems to comprehensively manage rainwater and flood control. This model is widely accepted because of its low processing cost and good processing effect. It can also be practiced in small and medium-sized cities in China as one of the directions to explore the current stage of urban rainwater management in China.

Different from the traditional "fast-draining" rainwater model, many experts and scholars in China have made new explanations on the nature of sponge cities and put forward new construction concepts (Che et al., 2002). Among the local laws and regulations, Beijing, Nanning and other cities require that new construction, reconstruction and expansion projects in various regions have guiding design patterns and engineering requirements for rainwater utilization in the construction of sponge cities, and formulate many measures for urban rainwater resource utilization (Wang et al., 2017).

The essence of the sponge city construction is to solve the problem of urban water. It is not only the rationality and validity of the measures of seepage, station, storage, purification and drainage should be considered, but also the physical properties of the sponge bearing body (rock and soil), as well as the danger of storing rainwater (including environmental geological problems) should be taken into account. The core content is closely related to environmental geology and hydrology. At present, domestic and foreign scholars still have different opinions on the construction model, essential connotation and viewpoins of the sponge city. They mostly study the "engineering measures" of the construction methods and technical modes (Du, 1996; Taylor, 2005; Wang, 1999), and overlooked the geological properties of the sponge capacity in the construction of sponge cities. They do not consider the overall evaluation of the environmental geological suitability of the construction area or planning area of sponge cities. Moreover, because of the lack of funds, most studies only stay in the theoretical research stage (Keller, 1999; Lloyd, 2002; Eslami, 1995), and have not been put into practice.

Therefore, in order to evaluate the suitability of sponge city construction, we should mainly consider the underground environmental bearing capacity and evaluate the original sponge environmental geological suitability from the geological point of view. This evaluation can effectively save the construction cost of sponge city and minimize 
the workload of sponge city, and have a definite object in view to achieve the goal of spongy city construction.

\section{Materials and methods}

The environmental geological suitability evaluation of sponge city construction is the premise of sponge city construction. The sponge capacity of geological body in sponge city construction directly affects the difficulty and complexity of city planning, scheme design and site construction. From the point of view of hydrogeology and environment geology, this paper mainly consider the bearing capacity of underground environment (Knödel, 2007; Argent, 2008; Rooijen, 2010). Based on a large number of in-situ water infiltration tests and boreholes, two indexes that sponge infiltration and sponge storage are put forward to study and analyze the maximum depth of rainfall infiltration and the infiltration velocity of surface soil under the original sponge geological conditions. These two indexes can directly and effectively represent and summarize the environmental geological suitability in the construction of sponge cities. They are easy to get and understand, have strong universality and are easy to popularize. Completing the evaluation of environmental geology suitability in sponge city construction can reduce the difficulty and workload of urban planning investigation, design and construction, and provide ideas and reference for urban agglomeration sponge city construction planning and design.

\section{Sponge infiltration capacity}

Sponge infiltration refers to the capacity of urban "sponge body" to infiltrate rainfall (rainfall infiltration coefficient): Assuming under an ideal condition (an atmospheric pressure, a hydraulic gradient of one, only vertical infiltration is considered) and during the whole rainfall infiltration process (Figs. 1 and 2), the water seepage speed during the complete infiltration process of different soil layers is $V_{\mathrm{i}}$ :

$$
V_{\mathrm{i}}=\frac{Q}{t_{\mathrm{i}}}
$$

$V_{i}$ : Water seepage velocity in different soil layers; $t_{\mathrm{i}}$ : Complete infiltration time in different soil layers.

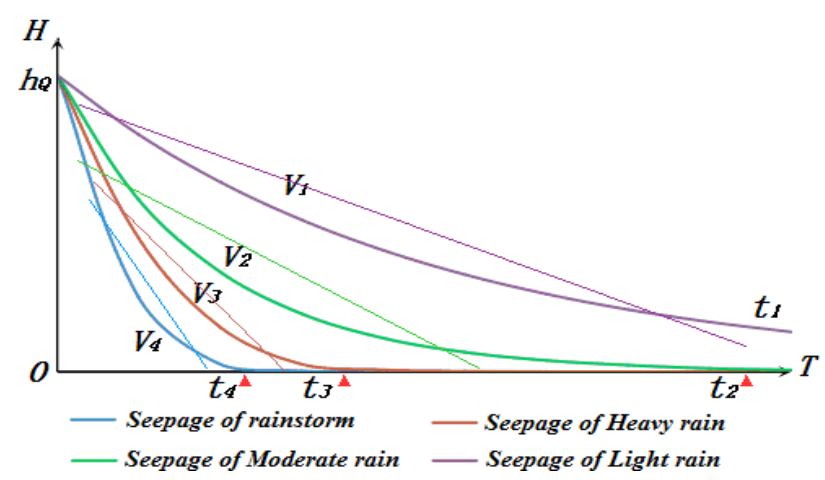

Figure 1. Rainfall infiltration curves in different soil formations 


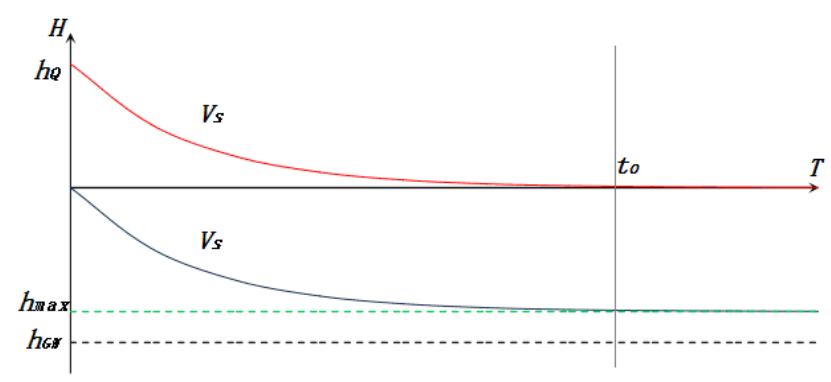

Figure 2. Schematic diagram of rainfall infiltration curve. (A: The area of the region; $Q$ : Maximum rainfall in 30 years; $V_{s}$ : Rainwater infiltration rate; $h_{\text {max }}$ : Maximum infiltration depth of rainfall; $h_{G w}$ : Depth of groundwater; to: The time required for total infiltration of rainfall; $n$ : Weighted effective porosity in penetration depth; $h_{Q}$ : The height of the rainfall within the area)

\section{Sponge storage capacity}

In the construction of the sponge city, the capacity of the sponge storage refers to the ability of the city "sponge body" to store rainwater (the size of aquifer storage space) and to solve urban water problems effectively (with the water supply capacity of phreatic layer).

Assuming an ideal state (an atmospheric pressure, a hydraulic gradient of 1, considering only vertical infiltration), the time required for complete rainfall infiltration is $t_{0}$, and the maximum depth of infiltration is $h_{\max }$ :

$$
h_{\max }=\frac{Q}{A \sqcap n}
$$

Due to equal water permeability, the seepage on the ground is equal to the seepage in the aeration zone.

The sponge capacity $P$ should be defined as: $P=\frac{h_{G W}}{h_{\max }}$

When $P>1, h_{G W}>h_{Q}$. This indicates that the geological environment (the thickness of the aerated zone) can fully withstand the maximum rainfall $Q$ in 30 years. It means that the city "sponge body" has sufficient rainfall storage capacity and water release capacity;

When $P=1, h_{G W}=h_{Q}$. This indicates that the geological environment just can withstand rainfall $Q$, and this is a critical state. To construct the sponge city, it is necessary to maintain the natural geological environment or take slight measures;

When $P<1, h_{G W}<h_{Q}$. This indicates that geological environment cannot withstand rainfall $Q$. It means that the city "sponge body" has enough rainfall storage capacity and water release capacity.

\section{Case study}

\section{Study area}

Xinxiang City is located in the north of Henan Province, China. It belongs to the North China Plate. It is located in the Yellow River and Haihe River Basins. The terrain 
is high in the north and low in the south. The northern part is mainly the Taihang Mountain and hilly land. The south is the alluvial fan plain of the Yellow River. The plains occupy $78 \%$ of the total land area of the city. The annual average precipitation is $573.4 \mathrm{~mm}$, of which precipitation is the most from June to September, accounting for $72 \%$ of the annual precipitation, and the annual evaporation is $1748.4 \mathrm{~mm}$. Xinxiang City has three national-level development zones and two provincial-level development zones, which are in a period of rapid urbanization and development.

A total of 123 sets of drilling points and 163 Investigation points information were obtained from the ground survey. The groundwater level in dry season and indoor seepage test data in the study area were collected, and 50 sets of field in-situ water seepage tests were carried out. The location distribution is presented in Figure 3.

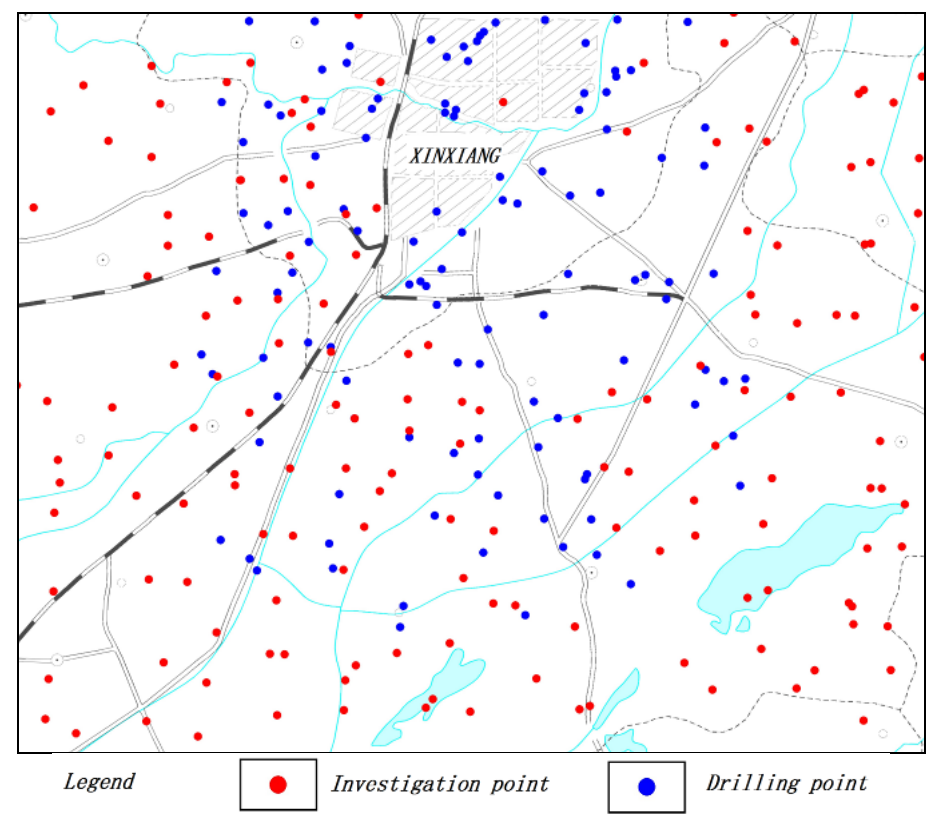

Figure 3. Distribution of research points

\section{Results and discussion}

Though a large number of field water seepage tests, a table (Table 1) of infiltration test results and their correspondent rainfall levels was obtained (Fig. 4).

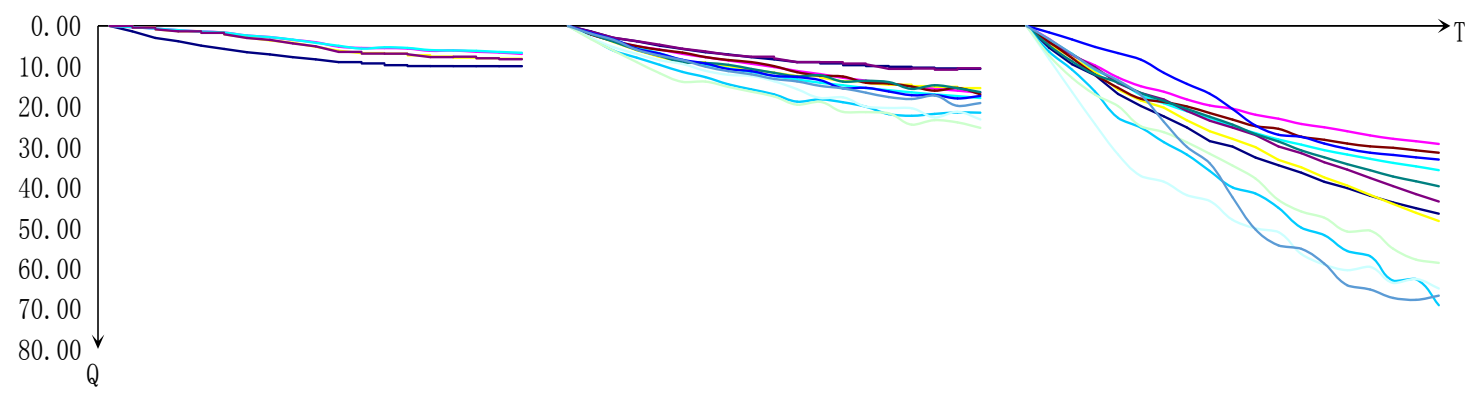

Figure 4. Infiltration curves corresponding to different rainfall levels 
The critical value of the corresponding seepage velocity is determined by the rainfall level in Table 1.

Table 1. Infiltration test results and their correspondent rainfall levels (rainfall does not produce runoff)

\begin{tabular}{c|c|c|c|c|c}
\hline Name of soil & $\begin{array}{c}\text { Water seepage } \\
\text { speed } \mathbf{~ m m / d}\end{array}$ & $\begin{array}{c}\text { Permeability } \\
\text { coefficient } \mathbf{~ c m} / \mathbf{s}^{-1}\end{array}$ & $\begin{array}{c}\text { Absorptive rainfall } \\
\text { intensity }\end{array}$ & \multicolumn{2}{|c}{$\begin{array}{c}\text { Rainfall level description } \\
(\mathbf{m m} / \mathbf{d})\end{array}$} \\
\hline Clay & 4.12 & $<1.2 * 10^{-6}$ & Light rain & Light rain & $0.1-9.9$ \\
Powder sticky & 5.18 & $1.2 \times 10^{-6}-6.0^{*} 10^{-5}$ & Light rain & Light rain & $0.1-9.9$ \\
Floury soil & 6.61 & $6.0 * 10^{-5}-6.0 * 10^{-4}$ & Light rain & Light rain & $0.1-9.9$ \\
Loess & 6.73 & $3.0^{*} 10^{-4}-6.0 * 10^{-4}$ & Light rain & Light rain & $0.1-9.9$ \\
Silt & 18.36 & $6.0^{*} 10^{-4}-1.2 * 10^{-3}$ & Moderate rain & Moderate rain & $10-24.9$ \\
Fine sand & $22.75-31.76$ & $1.2 * 10^{-3}-6.0 * 10^{-3}$ & Heavy rain & Heavy rain & $25-49.9$ \\
Medium sand & $57.86-81.32$ & $6.0^{*} 10^{-3}-2.4 * 10^{-2}$ & Rainstorm & Rainstorm & $50-99.9$ \\
Coarse sand & $87.46-125.23$ & $2.4 * 10^{-2}-6.0 * 10^{-2}$ & Downpour & Downpour & $100-249.9$ \\
Gravel & $289.26-342.32$ & $6.0^{*} 10^{-2}-1.8 * 10^{-1}$ & Heavy downpour & Heavy downpour & $>250$ \\
\hline
\end{tabular}

When $V<6.0^{*} 10^{-4}$, the surface soil layer can only accept the precipitation of light rain;

When $6.0^{*} 10^{-4}<V<1.2^{*} 10^{-3}$, the surface soil layer can only accept moderate rainfall;

When $1.2 * 10^{-3}<V<6.0 * 10^{-3}$, the surface soil layer can accept heavy rain;

When $6.0^{*} 10^{-3}<V$, the surface water can accept the precipitation above the level of the heavy rain;

Based on the measured data and experimental results, the sponge seepage capacity and the $\mathrm{P}$ results of sponge storage capacity of Xinxiang sponge city is divided:

Figure 5 shows that the evaluation of sponge seepage capacity is poor in the study area, only $3 \%$ of the area infiltration rate reaches the level of heavy rain in the region, rainwater can directly infiltrate the surface aerated zone to recharge the shallow aquifer in rainy season. Rainwater does not generate rainfall-runoff, causing surface water. This area can be directly used for the water seepage construction of sponge cities. About $26.5 \%$ of the area with medium-rainfall infiltration capacity is distributed in the southwest and central part of the region. Rainfall can not fully infiltrate the surface aerated zone to recharge the shallow aquifer in rainy season. Surface runoff and surface water will be formed. In the initial stage of the construction of sponge city, it is necessary to carry out the water seepage construction of sponge city after the improvement of the sponge seepage capacity by paving with water permeability or adding engineering facilities such as grass planting ditch and vegetation buffer zone. $70 \%$ of the area only reaches the level of light rain, poor infiltration capacity, when rainwater conditions will form a large number of rainfall-runoff and lead to surface water. The intervention of artificial conditions and high cost of engineering construction, it is not appropriate to directly or selectively carry out the water seepage construction of sponge cities. 


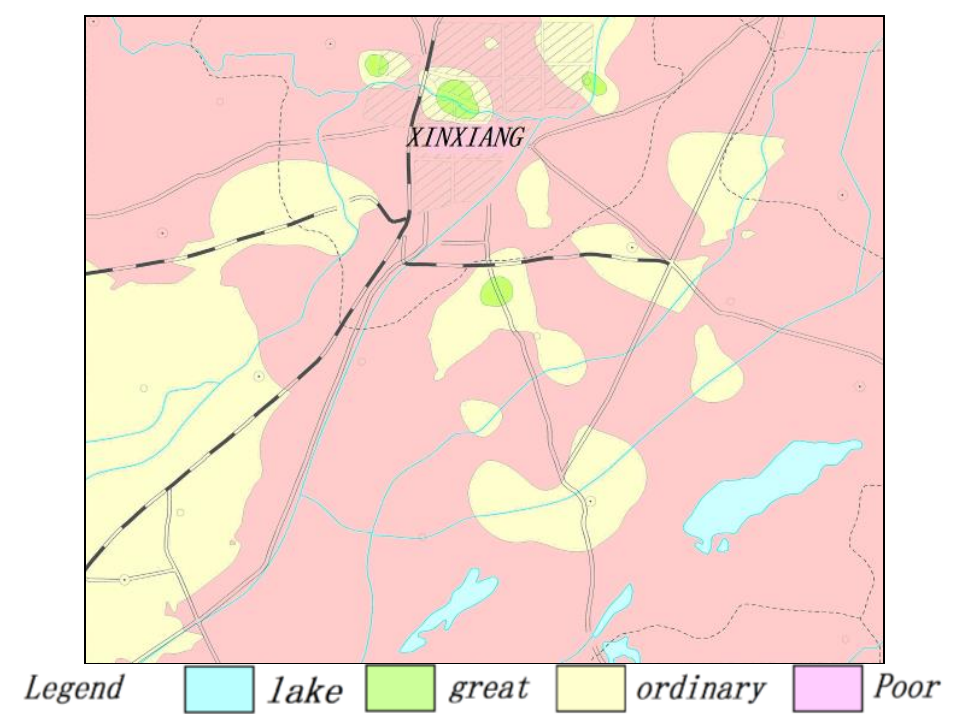

Figure 5. The V results of sponge seepage capacity in Xinxiang sponge City

Figure 6 shows that the evaluation of sponge storage capacity is preferably in the study area, $62 \%$ of the area can meet the annual rainfall. In rainy season, the water storage capacity of the surface aerated zone is enough to withstand rainfall infiltration and will not produce surface water. This area can be directly used for water storage construction of sponge city. In rainy season, 35.5\% of the surface aerated zone in the region is in the critical range of water storage capacity, and some low-lying areas may produce surface water. In the early stage of the construction of sponge city, slope drainage should be carried out, or additional engineering facilities such as reservoirs and artificial lakes should be installed to improve the water storage capacity of sponge city. $2.5 \%$ of the area in the region has poor water storage capacity, can not withstand rainfall when rainwater conditions lead to surface water, and the intervention of artificial conditions and high cost of Engineering construction, it is not appropriate to directly or selectively carry out the water storage construction of sponge cities.

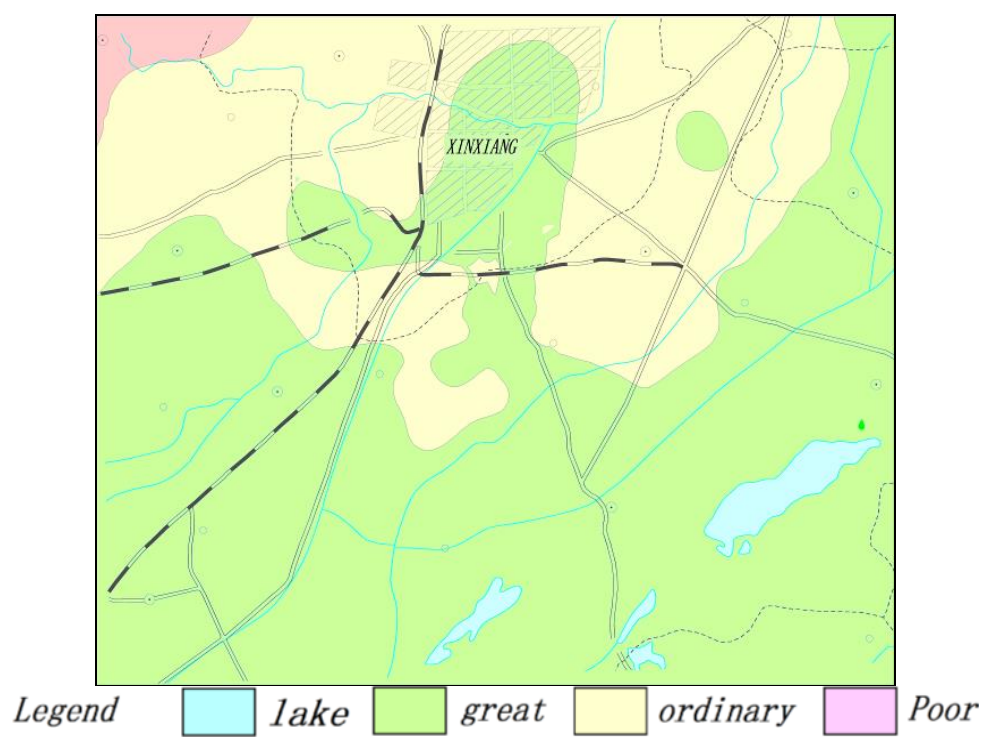

Figure 6. The P results of sponge storage capacity in Xinxiang sponge City 


\section{Conclusions and future work}

The environmental geological suitability evaluation of sponge city construction is the premise of sponge city construction. The sponge capacity of geological body in sponge city construction directly affects the difficulty and complexity of city planning, scheme design and site construction. From the point of view of hydrogeology and environment geology, this paper mainly consider the geological properties of sponge capacity in the construction of sponge city. Based on a large number of in-situ water infiltration tests and boreholes, two indexes that sponge infiltration and sponge storage are put forward to study and analyze the maximum depth of rainfall infiltration and the infiltration velocity of surface soil under the original sponge geological conditions. These two indexes can directly and effectively represent and summarize the environmental geological suitability in the construction of sponge cities. They are easy to get and understand, have strong universality and are easy to popularize. Completing the evaluation of environmental geology suitability in sponge city construction can reduce the difficulty and workload of urban planning investigation, design and construction, and provide ideas and reference for urban agglomeration sponge city construction planning and design.

According to the sponge seepage ability and the sponge water storage ability, the environmental geological suitability of Xinxiang sponge city was evaluated by two indexes. The sponge seepage ability in the study area was obviously superior to the sponge seepage ability, which was consistent with the field investigation results. In addition, some suggestions on the construction of sponge cities are given for the regions with insufficient infiltration and storage capacity to digest the maximum rainfall.

In this paper, the ideal state hypothesis is made in the environmental suitability index of sponge city construction, and the sponge purification capacity is also an important link in the construction of sponge city. Which are insufficient and slightly rough. Besides the sponge seepage and the sponge water storage capacity should be considered simultaneously, which should be the direction and focus of further research.

Acknowledgements. This paper was supported by the National key R \& D projects of China (No 2018YFC1803302) and National Nature Fund of China (No 41602261; No 41807231; No 41272301), Basic research projects of CAGS (YYWF201628).

\section{REFERENCES}

[1] Argent, N., Rolley, F., Walmsley, J. (2008): The sponge city hypothesis: does it hold water? - Australian Geographer 39(2): 109-130.

[2] Benedict, M. A. (2000): Green Infrastructure: A Strategic Approach to Land Conservation. PAS Memo. - American Planning Association, Chicago, IL.

[3] Burns, M. J., Fletcher, T. D., Walsh, C. J., et al. (2012): Hydrologic shortcomings of conventional urban stormwater management and opportunities for reform. - Landscape \& Urban Planning 105(3): 230-240.

[4] Carter, T., Jackson, C. R. (2007): Vegetated roofs for stormwater management at multiple spatial scales. - Landscape \& Urban Planning 80(1): 84-94.

[5] Che, S. Q., Xie, C. K., Chen, D., et al. (2015): Development and Constructive Approaches for Theories and Technologies of Sponge City System. - Chinese Landscape Architecture 31(6): 11-15. 
[6] Che, W., Li, J. Q. (2002): Recent status and prospect of urban rainwater utilization. Water Waste Eng 3: 12-14.

[7] CIRIA (2005): SUDS: Sustainable Drainage Systems: Promoting Good Practice - A CIRIA Initiative. - CIRIA, London.

[8] Council, N. R. (2008): Urban stormwater management in the United States. - National Research Council, Washington, DC.

[9] Dong, S., Han, Z. (2011): Study on planning an "eco-sponge city" for rainwater utilization. - Urban Studies 18: 37-41.

[10] Du, S. (1996): Geologic radar and its application in environmental geology. Geophysical \& Geochemical Exploration 1996.

[11] Eslami, M. R., Mahbadi, H. (1995): Some problems of ecological environmental geology in arid and semiarid areas of China. - Environmental Geology 26(1): 64-67.

[12] Gantner, K. (2003): Nachhaltigkeit urbaner Regenwasserbewirtschaftungsmethoden - Teil 1: Grundlagen. - GWF Wasser und Abwasser 3: 240-247.

[13] Geiger, W., Dreiseitl, H. (2001): Neue Wege für das Regenwasser: Handbuch zum Rückhalt und zur Versickerung von Regenwasser in Baugebieten. - München Oldenbourg Industry Verlag GmbH, Muenchen.

[14] Hoyer, J. (2011): Water Sensitive Urban Design - Principles and Inspiration for Sustainable Stormwater Management in the City of the Future. - Jovis Publishing Co., Berlin, pp. 79-87.

[15] Hu, C. W. (2015):”Sponge city" reconstructing urban water ecology. - Ecol Econ. 31(7): 10-13.

[16] Hu, N., Li, X., Ge, X. Y. (2015): Change with water-the rational cognition of sponge city system from the perspective of urban green space system. - Chinese Landscape Architecture 31(6): 21-25.

[17] Jayasooriya, V. M. (2014): Tools for modeling of stormwater management and economics of green infrastructure practices: a review. - Water Air Soil Poll 225(8): 2055.

[18] Ji, L. Y. (2014): Rainstorm management strategy and site planning practice for low impact development: an empirical analysis of North American countries. - Proceedings of the Conference on Urban Development and Planning. NC University of Technology.

[19] Keller, E. A. (1999): Introduction to Environmental Geology (4th Ed.). - Prentice Hall, Upper Saddle River, NJ.

[20] Knödel, K., Lange, G., Voigt, H. (2007): Environmental Geology: Handbook of Field Methods and Case Studies. - Springer, Heidelberg, pp. 25-33.

[21] Lloyd, S. D., Wong, T. H., Porter, B. (2002): The planning and construction of an urban stormwater management scheme. - Water Science \& Technology 45(7): 1.

[22] Martin, P. (2001): Sustainable Urban Drainage Systems: Best Practice Manual for England, Scotland, Wales and Northern Ireland. - Constr Ing Res \& Inf Assoc, London.

[23] Ministerium für Umwelt und Naturschutz, Landwirtschaft und Verbraucherschutz des Landes Nordrhein-Westfalen (2001): Naturnahe Regenwasserbewirtschaftung. - WAZ, Duisburg.

[24] Qiu, B. X. (2015): The connotation, ways and prospects of Spongy City (LID). - Constr S\&T, (7): 11-18.

[25] Revit, M. (2003): Report 5.1: Review of the Use of Storm Water BMPs in Europe. EVK1-CT-2002-00111.

[26] Romnée, A. (2015): Methodology for a stormwater sensitive urban watershed design. - J Hydrol 530: 87-102.

[27] Rooijen, D. J. V., Turral, H., Biggs, T. W. (2010): Sponge city: water balance of mega-city water use and wastewater use in Hyderabad, India. - Irrigation \& Drainage 54(S1): S81-S91.

[28] Roy, A. H., Wenger, S. J., Fletcher, T. D., et al. (2008): Impediments and solutions to sustainable, watershed-scale urban stormwater management: lessons from Australia and the United States. - Environmental Management 42(2): 344-359. 
[29] Song, Y., Yu, K. J. (2007): The landscape planning approach to construct administration system of city storm water: a case study of Weihai City. - Urban Problems 2007(8): 6470.

[30] Taylor, G. D, Fletcher, T. D., Wong, T. H. F., et al. (2005): Nitrogen composition in urban runoff--implications for stormwater management. - Water Research 39(10): 19821989.

[31] US EPA (United States Environmental Protection Agency) (2000a): Low Impact Development (LID): A literature review. - EPA-841-B-00-005, Office of Water, Washington, D.C.

[32] US EPA (United States Environmental Protection Agency) (2000b): Terminology of Low Impact Development. - EPA-841-N-12-003B, Office of Water, Washington, D.C.

[33] Wang, H., Mei, C., Liu, J. H. (2017): Systematic construction pattern of the sponge city. - J Hydraul Eng 48(9): 1009-1014.

[34] Wang, J. B., Zhao, J. S., Shen, Z. Y. (2017): Discussion about the two rainfall control approaches in Sponge City Construction. - J Hydraul Eng 48(12): 1490-1498.

[35] Wang, L., Ma, C. (1999): A study on the environmental geology of the Middle Route Project of the South-North water transfer. - Engineering Geology 51(3): 153-165.

[36] Wang, N., Wu, L. F. (2015): Practice and thinking of compiling sponge city construction plan in Xiamen. - Water Waste Eng 6: 28-32.

[37] Wanielista, M. P., Yousef, Y. A. (1993): Stormwater Management. - Elsevier, Amsterdam.

[38] Wu, D. J., Zhan, S. Z., Li, Y. H. (2016): New trends and practical research on the sponge cities with Chinese characteristics. - China Soft Science (1): 79-97.

[39] Yu, K. J., Li, D. H., Yuan, H. (2015): "Sponge City": theory and practice. - City Planning Review 39(6): 26-36.

[40] Zhang, J. Y., Wang, Y. T., Hu, Q. F. (2016): Discussion and views on some issues of the sponge city construction in China. - Adv Wat Sci 27(6): 793-799.

[41] Zou, Y. X., Yi, Q., Qiu, C. H. (2015): The research on sponge city construction in southern hilly area-a case study of Ningxiang County in Hunan Province. - Econ Geogr 35(9): 65-71. 